Vol. 3, No 1, Juni 2020

Hal 1-13

\title{
KAJIAN PEMANFAATAN WILAYAH PESISIR DAN LAUT KECAMATAN TANALILI KABUPATEN LUWU UTARA BERBASIS ZONASI KAWASAN
}

\author{
(Study of Land Used Coastal and Marine Areas in Tanalili District North Luwu \\ Regency Based on Zoning Area)
}

\author{
Akram 1), Abdul Rauf 2) dan Rustam 2) \\ 1) Mahasiswa Pasca-Sarjana Universitas Muslim Indonesia \\ 2) Dosen Program Manajemen Pesisir dan Teknologi Kelautan UMI Makassar
}

Korespondensi: akramabubakar22@gmail.com

Diterima: tanggal 5 Januari 2020; Disetujui 15 Febaruari 2020

\begin{abstract}
The coastal area of Tanalili District has many coastal and marine natural resources. However, its utilization has not been well managed and has resulted in uncontrolled utilization. This research aimed to: (1) Identify the condition and potential of coastal natural resources (2) Analyze the suitability of land to its designation (3) Integrate land use zoning (4) Determine coastal and marine area development strategies. This research was conducted in January to March 2018. Potential of coastal resources, land suitability and zoning were analyzed using a Geographic Information System (GIS) and SWOT for development analysis. The results of this study indicate the area of $96.38 \mathrm{Ha}$ mangrove ecosystem, seagrass 31,68 Ha, coral reefs 192,81 Ha. Zoning area showed a general utilization area of 6.132,49 Ha which was divided into 4 zones; aquaculture zone with an area of 1.012,31 Ha, capture fisheries zone with an area of 4.875,76 Ha, a port zone with an area of 46,91 Ha and other zones covering an area of 197,51 Ha. The area of marine protected area is 1,393.99 Ha and the regional sea lanes for shipping activities is 526.88 Ha. The results of the development policy analysis were the provision of a potential data base, the formation of business groups in accordance with the potential, compilation of management plans according to zoning, improvement of human resources quality both the community and related stakeholders and rehabilitation programs to control physical damage to the coast and ecosystems by involving the community.
\end{abstract}

Keywords: Study, Coastal, Suitability, Zoning, Tanalili

\begin{abstract}
ABSTRAK
Wilayah pesisir Kecamatan Tanalili memiliki banyak sumberdaya alam pesisir dan laut, namun pemanfaatannya belum dikelolah dengan baik dan menimbulkan pemanfaatan yang tidak terkendali. Penelitian ini dilakukan dengan tujuan untuk: (1) Mengidentifikasi kondisi dan potensi sumberdaya alam pesisir (2) Menganalisa kesesuaian lahan terhadap peruntukannya (3) Mengintegrasikan zonasi pemanfaatan lahan (4) Menentukan strategi pengembangan kawasan pesisir dan laut. Penelitian ini dilaksanakan pada bulan Januari sampai Maret 2018. Potensi sumberdaya pesisir, kesesuaian lahan dan zonasi dianalisis menggunakan Sistem Informasi Geografis (SIG), sedangkan untuk analisis pengembangannya menggunakan analisis SWOT. Hasil penelitian ini menunjukan luas ekosistem mangrove 96,38 Ha, padang lamun 31,68 Ha, terumbu karang 192,81 Ha. Zonasi kawasan menunjukan kawasan pemanfaataan umum seluas 6.132,49 Ha yang dibagi menjadi 4 zona, yaitu; zona perikanan budidaya dengan luas 1.012,31 Ha, zona perikanan tangkap dengan luas 4.875,76 Ha, zona pelabuhan dengan luas 46,91 Ha dan zona lainnya seluas 197,51 Ha. Luas kawasan konservasi perairan seluas 1.393,99 Ha dan kawasan alur laut untuk kegiatan pelayaran seluas 526,88 Ha. Hasil analisis kebijakan pengembangan adalah penyediaan data base potensi, pembentukan kelompok usaha sesuai potensi, menyususn rencana pengelolaan sesuai zonasi, meningkatkan kualitas sumberdaya manusia baik itu masyarakat maupun stakeholder yang terkait dan melakukan program pengendalian kerusakan fisik pesisir dan ekosistem dengan rehabilitasi dengan melibatkan masyarakat.
\end{abstract}

Kata kunci: Kajian, Pesisir, Kesesuaian, Zonasi, Tanalili 


\section{PENDAHULUAN}

Kecamatan Tanalili merupakan salah satu kecamatan pesisir yang ada wilayah Kabupaten Luwu Utara Provinsi Sulawesi Selatan. Sebagai kecamatan pesisir, wilayah ini memiliki banyak sumberdaya alam pesisir dan laut yang belum dimanfaatkan dengan baik. Sumberdaya alam pesisir wilayah ini antara lain ekosistem mangrove, ekosistem terumbu karang, ekosistem dan padang lamun serta sumberdaya perikanan baik budidaya maupun perikanan tangkap. Sumberdaya tersebut masing-masing memiliki fungsi ekologis yang sangat penting.

Pemanfaatan wilayah pesisir di Kecamatan Tanalili didominasi oleh perikanan budidaya laut yang sebagian besar merupakan budidaya rumput laut dengan jumlah produksi tahun 2017 sebesar $32.758,10$ Ton, untuk budidaya air payau jumlah produksinya sebesar 158.712,78 Ton sedangkan untuk perikanan tangkap jumlah produksinya sebesar 1.716,50 Ton (BPS Luwu Utara, 2018).

Selama ini pemanfaatan wilayah pesisir dan laut di Kecamatan Tanalili belum dikelolah dengan baik sehingga menimbulkan pemanfaatan yang tidak terkendali. Pada tahun 2019 Pemerintah Provinsi Sulawesi Selatan menerbitkan Peraturan Daerah Nomor 2 tentang Rencana Zonasi Wilayah Pesisir dan Pulau-Pulau Kecil (RZWP-3-K) Provinsi Sulawesi Selatan. Dengan adanya Peraturan Daerah RZWP-3-K ini diharapkan mampu menjadi landasan dalam pemanfatan wilayah pesisir dan laut, dalam aplikasinya masih belum mengakomodasi semua pemanfaatan wilayah pesisir khusus wilayah pesisir sekitar Kecamatan Tanalili, oleh karena itu dilakukan penelitian yang bertujuan untuk mengkaji pemanfaatan wilayah pesisir dan laut Kecamatan Tanalili Kabupaten Luwu Utara berbasis zonasi kawasan.

\section{MATERI DAN METODE}

\section{- Waktu dan Tempat Penelitian}

Kegiatan penelitian ini dilakukan pada bulan Januari - Maret 2018, di wilayah pesisir Kecamatan Tanalili Kabupaten Luwu Utara Provinsi Sulawesi Selatan. 


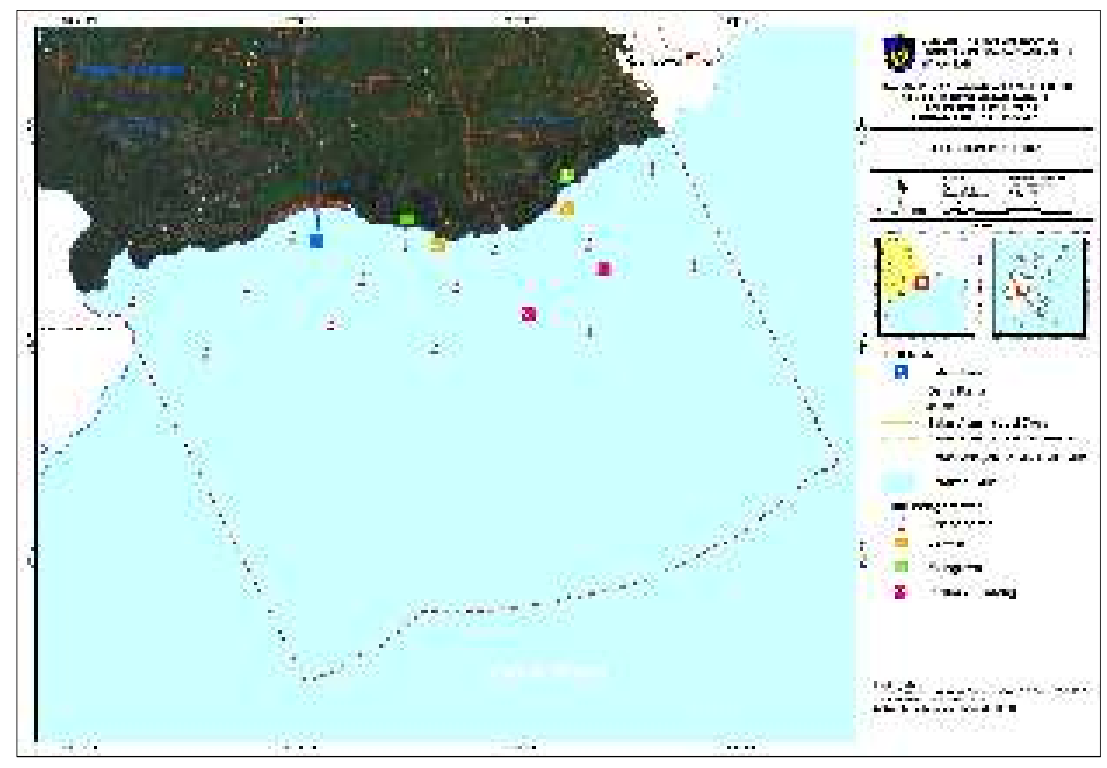

Gambar 1. Peta lokasi penelitian

\section{- Alat dan Bahan}

Alat dan bahan yang digunakan dalam penelitian ini yaitu alat selam (SCUBA diving), alat tulis dan kamera bawah air, GPS untuk penentuan posisi stasiun, thermometer untuk mengukur suhu perairan, $\mathrm{pH}$ meter untuk mengukur $\mathrm{pH}$, DO meter untuk mengukur oksigen terlarut, handrefraktometer untuk mengukur salinitas, layangan arus untuk menetukan kecepatan arus, secchi disk untuk mengukur tingkat kecerahan, spektrofotometer untuk mengukur nitrat dan fosfat, aplikasi GIS, Peta RBI Skala 1:50.000 BIG tahun 2017, Citra Satelit SPOT 6 tahun 2017.

\section{- Jenis dan Sumber Data}

Data dari penelitian ini terdiri dari data primer dan data sekunder. Data primer hasil dari survei berupa data ekosistem pesisir, data oseanografi, sosial budaya masyarakat dan data pemanfaatan wilayah pesisir, sedangkan data sekunder berupa data yang diperoleh dari instansi terkait berupa peta RBI, Citra Satelit dan Alokasi Ruang RZWP-3- Provinsi Sulawesi Selatan.

\section{- Teknik Pengumpulan Data}

Pengumpulan data pada penelitian ini dilakukan dengan cara sebagai berikut: 1) Survei Lapangan: Mengumpulkan informasi mengenai kondisi potensi ekositem pesisir, kondisi oseanografi dan kondisi pemanfaatan wilayah pesisir; 2) Wawancara: Dilakukan tanya jawab dengan masyarakat sekitar, unsur birokrasi, akademisi, pelaku usaha, dan lembaga swadaya masyarakat (LSM) 
yang peduli pada pengelolaan pesisir; dan 3) Studi Dokumentasi: Mengumpulkan data berupa dokumen geospatial berupa Peta Rupa Bumi Indonesia dan Citra satelit SPOT 6 serta studi dokumentasi mengenai kondisi topografi dan morfologi wilayah kajian.

\section{- Metode Analisis Data}

Untuk menjawab permasalahan dalam penelitian maka digunakan analisis data sebagai berikut:

\section{Analisis kondisi sumberdaya pesisir}

a. Oseanografi: parameter oseanografi ditabulasi dan dianalisis dengan metode interpolasi pada aplikasi interpolasi Sistem Informasi Geografis (SIG) untuk menghasilkan peta tematik.

b. Ekosistem pesisir

- Kerapatan mangrove

$$
\mathrm{K}=\frac{\mathrm{S} \text { Individu Jenis } \mathrm{i}}{\mathrm{S} \text { Plot (Luas ) }} \times 10.000
$$

Status kondisi padat $(\geq 1.500$ pohon/Ha), sedang (1.000-1.500 pohon/Ha), dan jarang $(<1.000$ pohon/Ha) (KLHK, 2004).

- Persentase Tutupan Padang Lamun $\frac{\text { Jumlah tutupan transek }}{\text { Jumlah kuadrat transek }} \times 100 \%$ Stastus kondisi kaya/sehat $(\geq 60$ \%), kurang kaya/kurang sehat $(30-59,9 \%)$, dan miskin ( $\leq$ 29,9 \%) (KLHK, 2004).

- Persentase Tutupan Terumbu Karang

persentase tutupan setiap foto frame dihitung berdasarkan rumus sebagai berikut:

$$
=\frac{\text { Jumlah titik kategori }}{\text { Banyaknya titik acak }} \times 100 \%
$$

Status kondisi rusak (0-24,9\%), sedang (25-49,9\%), baik (50-74,9\%) dan sangat baik (75-100\%) (Gomez dan Yap, 1988).

\section{Analisis kesesuaian lahan}

Analisis kesesuaian lahan dengan overlay menggunakan indeks overlay model (Benham dan Carter, diacu dalam Candra, 2003). Model matematis disajiakan sebagai berikut:

$$
\mathrm{S}_{\mathrm{X}}=\frac{\sum \mathrm{Sij}_{\mathrm{X}} \mathrm{Wi}}{\sum \mathrm{Wi}}
$$

Keterangan;

$\mathrm{S}_{\mathrm{x}}=$ Indeks terbobot poligon terpilih

$\mathrm{Sij}=$ Kelas ke-j dalam peta ke-i $\mathrm{Wi}=$ Bobot peta ke-i 
Tabel 1. Matriks kesesuaian untuk budidaya rumput laut

\begin{tabular}{clccc}
\hline No & \multicolumn{1}{c}{ Parameter } & Sesuai $(\mathrm{S})$ & Tidak sesuai $(\mathrm{N})$ & Bobot $(\mathrm{B})$ \\
\hline 1. & Gelombang $(\mathrm{m})$ & $0,1-1,2$ & $>1,2$ & 10 \\
2. & Arus $(\mathrm{m} / \mathrm{dtk})$ & $0.1-0.4$ & $<0.1 \&>0.4$ & 10 \\
3. & Kedalaman $(\mathrm{m})$ & $0.5-5$ & $<0,5 \&>5$ & 15 \\
4. & Kecerahan $(\%)$ & $30-100$ & $<30$ & 10 \\
5. & Salinitas $(\%)$ & $28-34$ & $<28 \&>34$ & 10 \\
6. & Suhu $\left({ }^{\circ} \mathrm{C}\right)$ & $24-30$ & $<24 \&>30$ & 5 \\
7. & pH & $6-8.5$ & $>8.5$ & 5 \\
8. & DO & $4-8$ & $<4$ & 5 \\
9. & Nitrat $(\mathrm{mg} / \mathrm{l})$ & $0.01-1<0.01$ & $>1$ & 15 \\
10. & Fosfat $(\mathrm{mg} / \mathrm{l})$ & $0.10-0.30$ & $<0.10 \&>1$ & 15 \\
\hline
\end{tabular}

Sumber: Pedoman Teknis Penyusunan RZWP-3-K (2013)

Tabel 2. Parameter kesesuaian untuk Perikanan Tangkap

\begin{tabular}{|c|c|c|c|c|}
\hline \multirow{2}{*}{ No } & \multirow{2}{*}{ Parameter Kesesuaian } & \multirow{2}{*}{ Satuan } & \multicolumn{2}{|c|}{ Kriteria Kesesuaian } \\
\hline & & & Sesuai (S1) & Tidak Sesuai $(\mathrm{N})$ \\
\hline 1. & Kedalaman & $\mathrm{m}$ & $0-400$ & - \\
\hline 2. & Oksigen Terlarut (DO) & $\mathrm{mg} / \mathrm{L}$ & $>5$ & $<5$ \\
\hline 3. & Salinitas & $\%$ & $33-34$ & $<33 \& 34>$ \\
\hline 4. & Suhu & ${ }^{\circ} \mathrm{C}$ & $28-32$ & $<28 \& 32>$ \\
\hline 5. & Derajat Keasaman $(\mathrm{pH})$ & & $7-8,5$ & $<7-8,5>$ \\
\hline 6. & Tinggi Gelombang & $\mathrm{m}$ & $0-3$ & $>3$ \\
\hline 7. & Jumlah Hari Hujan & hari/tahun & $110-180$ & $<110$ \\
\hline 8. & Tutupan Karang & $\%$ & $20-80$ & $<20$ \\
\hline 9. & Tutupan Mangrove & $\%$ & $20-80$ & $<20$ \\
\hline 10. & Jarak Pantai & $\mathrm{Km}$ & $0-12$ & $>30$ \\
\hline
\end{tabular}

Sumber: Pedoman teknis penyusunan RZWP-3-K (2013)

\section{Analisis Zonasi Kawasan}

Hasil dari kesesuaian lahan dianalisis menggunakan analisis zonasi dengan mempertimbangkan semua pemanfatan yang telah ada di wilayah pesisir Kecamatan Tanalili menggunakan matriks keterkaitan antara kegiatan pemanfaatan ruang pesisir (Tabel 3). 
Tabel 3. Matriks keterkaitan antara kegiatan pemanfaatan ruang pesisir

\begin{tabular}{|c|c|c|c|c|c|c|c|c|}
\hline Alur pelayaran & \multicolumn{8}{|c|}{ Alur pelayaran } \\
\hline Pelabuhan & \multicolumn{8}{|c|}{$\mathrm{O} \mid$ Pelabuhan } \\
\hline Dermaga & \multicolumn{8}{|c|}{ 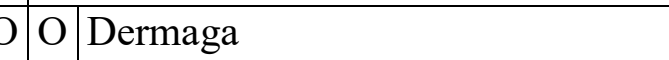 } \\
\hline Budidaya KJA & $\mathbf{X}$ & \multicolumn{7}{|c|}{ 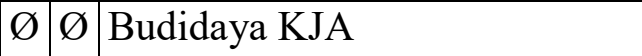 } \\
\hline Budidaya rumput laut & $\mathbf{X}$ & $\varnothing \ell$ & & -1 & \multicolumn{4}{|c|}{ Budidaya rumput laut } \\
\hline Penangkapan tradisional & $\mathbf{X}$ & $\overline{\varnothing \varnothing}$ & & $\mathbf{X}$ & \multicolumn{4}{|c|}{\begin{tabular}{|l|l|}
$\mathbf{X}$ & Penangkapan tradisional \\
\end{tabular}} \\
\hline Wisata selam & $\mathbf{X}$ & $\bar{\varnothing} \varnothing$ & & $\mathrm{K}$ & \multicolumn{4}{|c|}{\begin{tabular}{l|l|l}
$\mathbf{X}$ & $\mathbf{X}$ & Wisata selam \\
\end{tabular}} \\
\hline Wisata snorkling & $\mathbf{X}$ & $\bar{\varnothing} \varnothing$ & & $\bar{x}$ & $>1$ & \begin{tabular}{l|l|}
$\mathbf{X}$ & $\mathrm{O}$ \\
\end{tabular} & \multicolumn{2}{|c|}{ Wisata snorkling } \\
\hline Wisata mangrove & -1 & $\varnothing \varnothing$ & & - & - & -1 & \multicolumn{2}{|c|}{ Wisata mangrove } \\
\hline Konservasi & 4 & - & & - & 4 & 4 & $4 \mathrm{O}$ & Konservasi \\
\hline Alur migrasi biota & 4 & & & & & 4 & $-1-$ & Alur migre \\
\hline
\end{tabular}

Sumber: Pedoman teknis penyusunan RZWP-3-K (2013)

Ket: $\mathbf{\Psi}=$ Mengancam kegiatan di kiri, $>=$ Mengancam kegiatan di atas, $O=$ Kegiatan saling memberi manfaat positif, $X=$ Potensial menimbulkan konflik, $-=$ Netral, $\varnothing=$ Positif dengan kegiatan di kiri

\section{Analisis Penentuan Strategi} pengembangan Wilayah Pesisir

Perencanaan pengembangan

wilayah pesisir dilakukan dengan menggunakan analisis SWOT. Analisa SWOT merupakan instrumen perencanaan strategis yang klasik dengan menggunakan kerangka kerja kekuatan, kelemahan, kesempatan eksternal dan ancaman untuk memformulasikan strategi suatu kegiatan (Start dan Hovland, 2004).

\section{HASIL DAN PEMBAHASAN}

- Kondisi dan potensi sumberdaya pesisir

\section{Kondisi oseanografi}

Kondisi parameter oseanografi di sekitar wilayah kajian menunjukkan nilai yang bervariasi seperti parameter salinitasnya sekitar 26 33 ppt, suhu permukaan laut berkisar antara $28,1^{\circ} \mathrm{C}-30^{\circ} \mathrm{C}$. Nilai derajat keasaman $(\mathrm{pH})$ perairan antara $6,3-7,3, \mathrm{pH}$ yang ideal bagi organisme perairan pada umumnya terdapat antara 7 - 8,5 (Odum 1994 dalam Simamora 2009).

Untuk parameter oksigen terlarut (DO) di lokasi penelitian menunjukkan nilai berkisar 5,5 - 7,5 $\mathrm{mg} / \mathrm{l}$ dan posfat menunjukkan nialai $0,173-0,396 \mathrm{mg} / \mathrm{l}$, sedangkan nitrat bersekitar $0,052 \quad-\quad 1,468 \mathrm{mg} / \mathrm{l}$. 
Kecerahan perairan di sekitar lokasi penelitian antara 50 hingga $80 \%$.

a. Kedalam Perairan

Kedalam perairan disekitar wilah kajian sangat bervariasi berkiar 0,5 meter disekitar garis pantai dan semakin dalam ke arah laut dengan nilai kedalaman 20 meter diarea 2 mil dari garis pantai dan mencapai 45 meter di area 4 mil dari garis pantai (Gambar 1).

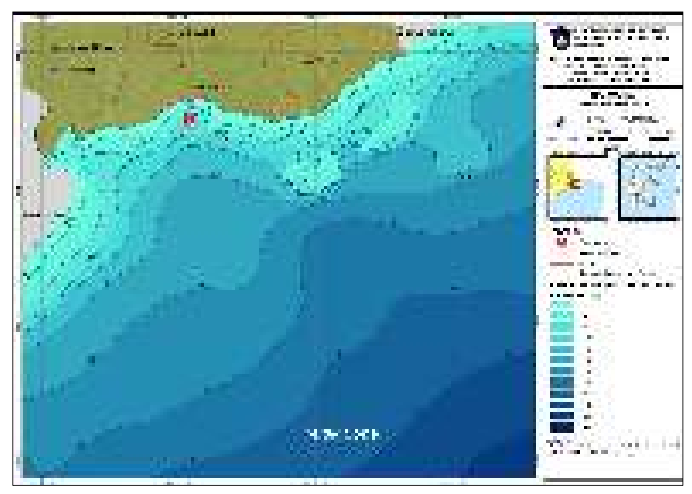

Gambar 1. Kedalaman perairan

b. Pasang Surut

Berdasarkan hasil pengamatan pada lokasi penelitian didapatkan Tipe pasang surut tipe semi diurnal yang artinya dalam satu hari terjadi dua kali pasang dan dua kali (Gambar 2).

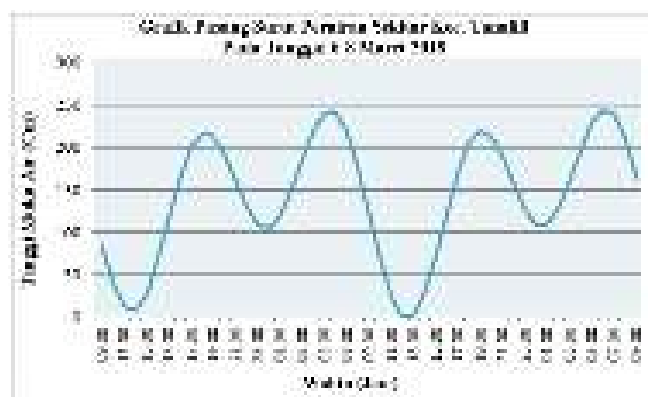

Gambar 2. Kondisi pasang surut c. Gelombang

Kondisi ketinggian gelombang berkisar antara $0,1-2,5$ meter pada musim barat dan musim timur. Gelombang pada musim barat merambat dari arah barat daya menuju ke pantai dan untuk gelombang musim timur merambat dari arah tenggara menuju pantai (Gambar 3).

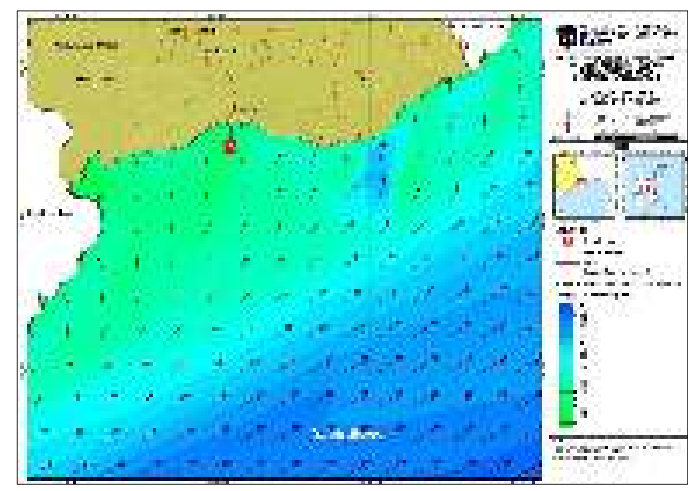

Gambar 3. Peta arah dan tinggi gelombang laut

d. Arus

Kecepatan arus perairan pada titik sampling di sekitar perairan Kecamatan Tanalili berdasarkan hasil tabulasi pengukuran berada pada kisaran $0,01 \quad-\quad 0,05$ meter/detik (Gambar 4). 


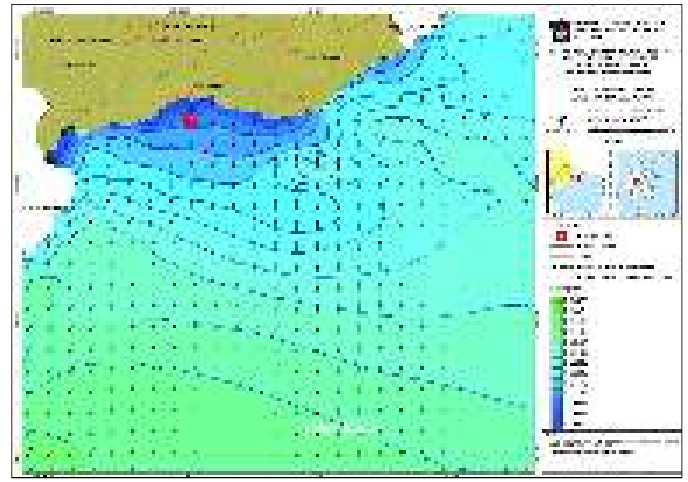

Gambar 4. Peta arah dan kecepatan arus kondisi menuju pasang tertinggi

\section{Pemanfaatan eksisting Sumberdaya Pesisir}

Pemanfaatan sumberdaya pesisir dewasa ini terdiri dari kegiatan: 1) budidaya ikan air payau seluas 1.222,35 Ha, 2) budidaya rumput laut seluas 1.311,09 Ha, 3) perikanan tangkap di daerah 1 - 4 mil laut. Pemanfaatan lain adalah konservasi yang dicadangkan oleh Gubernur Sulawesi Selatan dalam bentuk Kawasan Konservasi Perairan Daerah seluas 1.971,78 Ha. Selain pemanfaatan diatas terdapat juga pemanfaatan pelabuhan dengan luas area sekitar 31,68 Ha (Gambar $5)$.

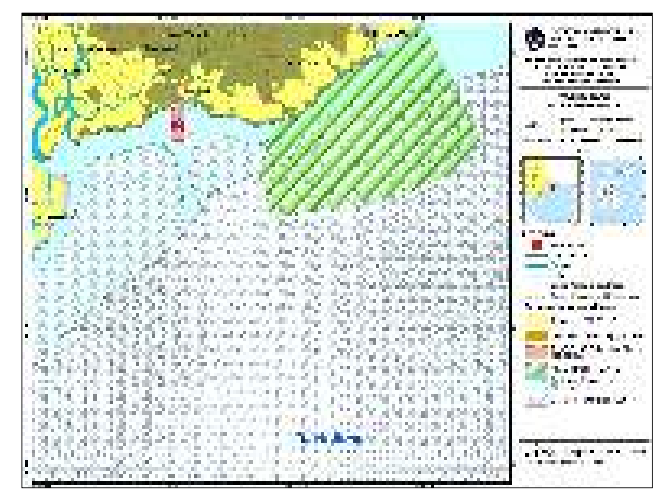

Gambar 5. Peta Pemanfaatan wilayah pesisir Kecamatan Tanalili

\section{Ekosistem Mangrove}

Sebaran ekosistem mangrove hasil interpretasi citra satelit seluas 96,38 Ha dengan 3 jenis yang ditemukan, yaitu; Rhizophora stylosa, Sonneratia alba dan Bruguiera cylindrica. Nilai kerapatan mangrove di sekitar untuk kategori pohon sebanyak $800 \mathrm{ind} /$ ha stasiun 1 sedangkan pada stasiun 2 sebanyak 600 ind/ha. Kerapatan anakan sebanyak $2800 \mathrm{ind} /$ ha pada stasiun 1 dan pada stasiun 2 sebanyak 4400, sedangkan kerapatan kategori semaian sebanyak $30000 \mathrm{ind} / \mathrm{ha}$ pada stasiun 1 dan stasiun 2 sebanyak 50000 (Gambar 6). Kondisi ini menunjukkan bahwa mangrove di sekitar wilayah pesisir ini masuk dalam kategori "Jarang”.
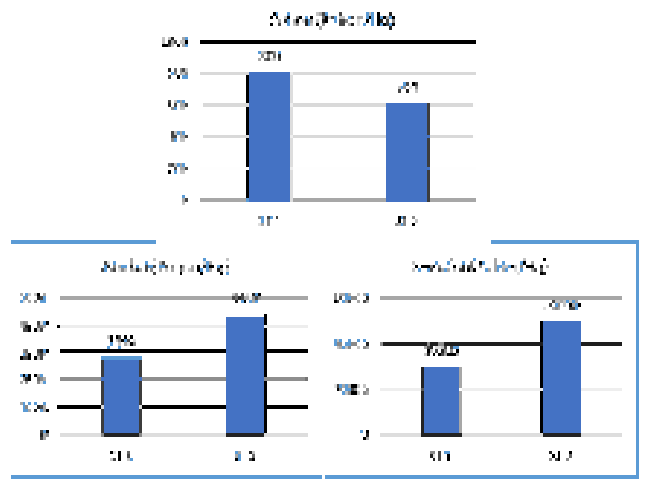

Gambar 6. Nilai kerapatan mangrove pohon, anakan dan semaian 


\section{Ekosistem Padang Lamun}

Luas ekosistem padang lamun hasil interpretasi citra satelit sekitar 31,68 Ha dengan 3 jenis lamun yang ditemukan, yaitu; Enhalus acoroides, Cymodocea serrulate dan Cymodocea rotundata. Persentase pada stasiun 01 sebesar $26,63 \%$ sedangkan stasiun 02 sebesar 16,31\%, nilai ini masuk dalam kategori “Miskin” (Gambar 7).

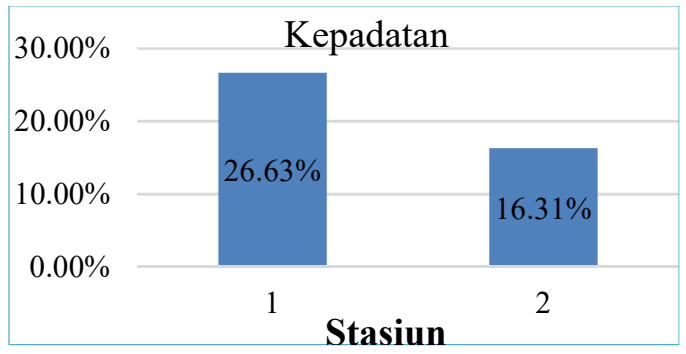

Gambar 7. Garfik persentase tutupan padang lamun

\section{Ekosistem Terumbu Karang}

Luas ekosistem terumbu karang hasil interpretasi citra satelit sekitar 192,81 Ha. Persentase tutupan karang hidup pada stasiun 1 yaitu; $11 \%$, tutupan abiotik sebesar $38 \%$ dan karang mati sebesar 51\%. Pada stasiun 2 tutupan karang hidup sebesar 37\%, tutupan abiotik sebesar $14,93 \%$ dan karang mati sebesar 34\% (Gambar 8). Kondisi tutupan karang pada satsiun 1 kategori
"Rusak" dan stasiun 2 pada kategori "Sedang".

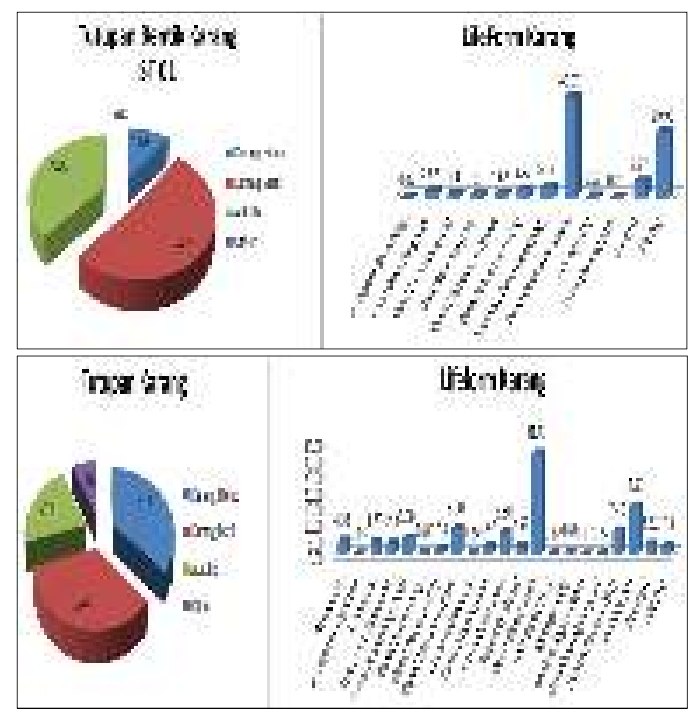

Gambar 8. Persentase tutupan terumbu karang

- Kesesuaian Lahan

\section{Budidaya rumput laut}

Hasil analisis kesesuaian lahan menunjukkan bahwa lokasi yang sesuai (S) untuk budidaya rumput laut seluas 1.801,37 $\mathrm{Ha}$ dan tidak sesuai (N) seluas $6.251,99 \quad \mathrm{Ha}$ (Gambar 9).

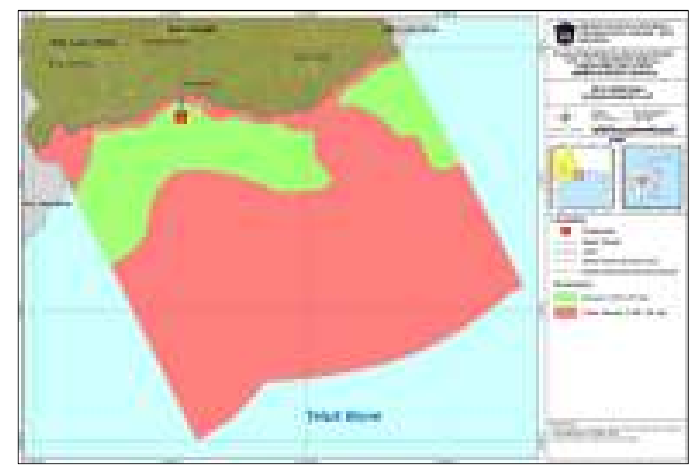

Gambar 9. Peta Kesesuaian untuk lokasi budidaya rumput laut 


\section{Perikanan Tangkap}

Berdasarkan hasil analisis untuk alokasi ruang diperoleh luas kawasan lokasi penangkapan ikan yang pemanfaataan umum seluas 6.132,49 sesuai didapatkan luas ai sebesar Ha yang dibagi menjadi 4 zona, yaitu; 6.093,07 Ha dan lokasi tidak sesuai zona budidaya dengan luas 1.012,31 sebesar 1.960,28 Ha (Gambar 10).

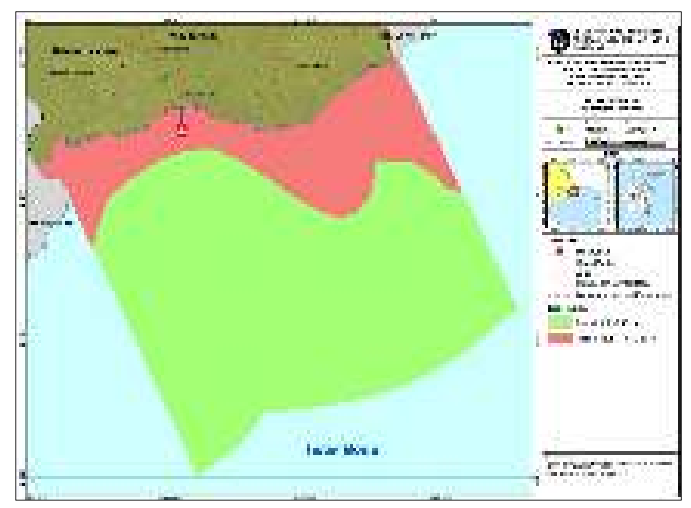

Gambar 10. Peta kesesuaian untuk lokasi perikanan tangkap

- Rencana Zonasi
Dari hasil analisis zonasi pada Ha, zona perikanan tangkap dengan luas 4.875,76 Ha, zona pelabuhan dengan luas 46,91 Ha dan zona lainnya seluas 197,51 Ha. Untuk kawasan konservasi berdasarkan data eksisiting yang telah termuat dalam RZWP-3-K Provinsi Sulawesi Selatan yang masuk dalam wilayah kajian dengan luas 1.393,99 Ha, sedangkan untuk kawasan alur laut untuk kegiatan pelayaran seluas 526,88 Ha (Tabel 5).

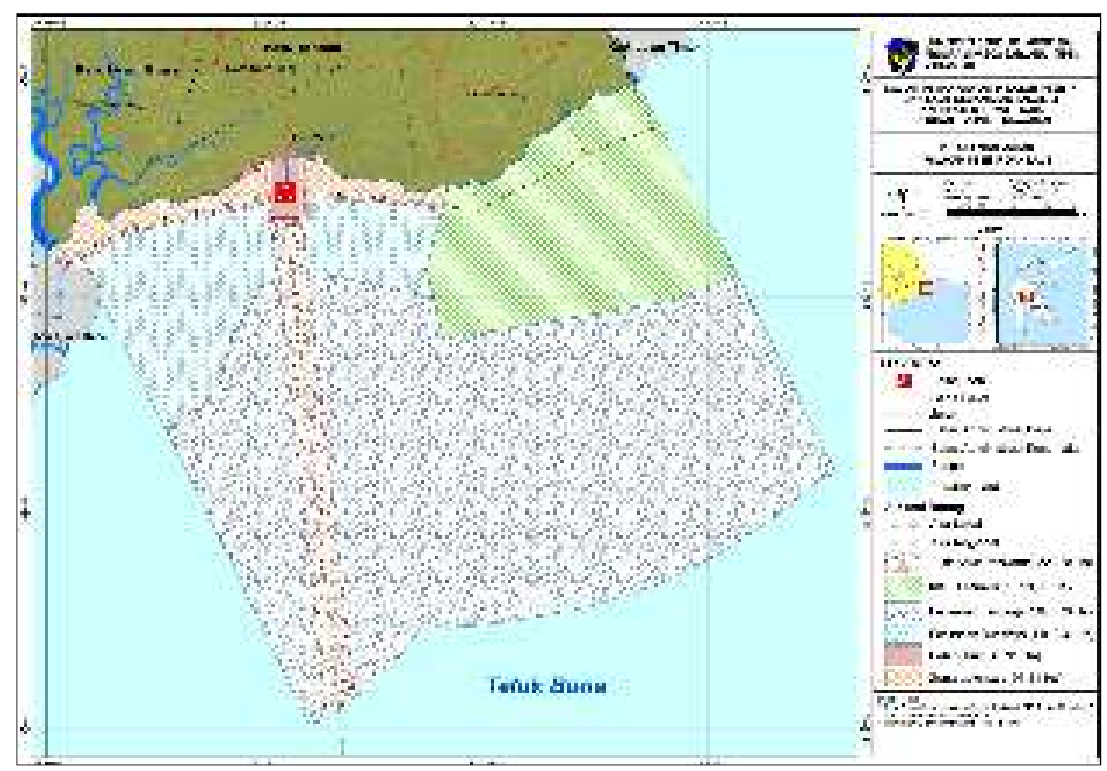

Gambar 11. Peta zonasi alokasi ruang 
Tabel 4. Luas zonasi alokasi ruang wilayah pesisir Kecamatan Tanalili

\begin{tabular}{|c|c|c|c|c|}
\hline No & Zona & Sumber & Luas $(\mathrm{Ha})$ & $(\%)$ \\
\hline 1. & KKPD & $\begin{array}{l}\text { RZWP-3-K Provinsi } \\
\text { Sulawesi Selatan }\end{array}$ & $1.393,99$ & 17,31 \\
\hline 2. & Perikanan Tangkap & Hasil Analisis & $4.875,76$ & 60,54 \\
\hline 3. & Budidaya & Hasil Analisis & $1.012,31$ & 12,57 \\
\hline 4. & Pelabuhan & $\begin{array}{l}\text { RZWP-3-K Provinsi } \\
\text { Sulawesi Selatan }\end{array}$ & 46,91 & 0,58 \\
\hline 5. & Lainya & Hasil Analisis & 197,51 & 2,45 \\
\hline 6. & Alur & Hasil Analisis & 526,88 & 6,54 \\
\hline \multicolumn{3}{|c|}{ Total } & $8.053,36$ & 100 \\
\hline
\end{tabular}

Sumber: Hasil Analisis 2020

\section{- Strategi Pengembangan Wilayah Pesisir}

Potensi pengembangan wilayah pesisir dan laut Kecamatan Tanalili Kabupaten Luwu Utara dianalisis dengan menggunakan analisis SWOT (Strength, Weaknesses, Opportunities, and Therats). Hasil analisis strategi pengembangan wilayah pesisir Kecamatan Tanalili ditetapkan 6 (enam) strategi antara lain;

Menyediakan data base potensi sumber daya pesisir (2) Meningkatan usaha dengan melibatkan masyarakat melalaui pembentukan kelompok usaha sesuai potensi pesisir dan produksi unggulan (3) Menyusun rencana pengelolaan berdasarkan pemetaan zonasi kawasan pesisir untuk menghindari terjadinya konflik pemanfaatan

Melakukan monitoring aktifitas yang sesuai arahan peraturan pemanfaatan ruang wilayah pesisir (5) Melakukan program pengendalian kerusakan fisik pesisir dan ekosistem dengan rehabilitasi ekosistem pesisir (6) Membuat manajemen pemanfaatan wilayah pesisir berbasis lingkungan dan berkelanjutan.

\section{KESIMPULAN}

1. Potensi sumberdaya ekosistem terumbu karang kondisinya "rusak" hingga "sedang”, ekosistem padang lamun dalam kondisi "miskin" dan ekositem mangrove dalam kondisi "jarang".

2. Kesesuaian lahan yang sesuai untuk budidaya rumput laut perikanan 
tangkap cukup luas namun belum dimanfaatkan secara optimal.

3. Kawasan yang ditetapkan terdiri dari 1) kawasan pemanfaataan umum, 2) Kawasan konservasi perairan, 3) Alur laut.

4. Strategi pengembangan wilayah pesisir Kecamatan Tanalili secara umum adalah penyediaan data base potensi, pembentukan kelompok usaha sesuai potensi, menyususn rencana pengelolaan sesuai zonasi, meningkatkan kualitas sumberdaya manusia dan melakukan program pengendalian kerusakan fisik pesisir dan ekosistem dengan rehabilitasi.

\section{SARAN}

1. Hasil penelitian ini dapat dijadikan sebagai bahan masukan dalam pengelolaan sumberdaya di wilayah Kecamatan Tanalili Kabupaten Luwu Utara.

2. Penelitian lanjutan dapat dilakukan dengan pengambilan data parameter kualitas air yang lebih banyak dan dilakukan pengukuran pada tiap musim untuk kesesuaian yang lebih beragam.

\section{UCAPAN TERIMA KASIH}

Hasil kajian ini merupakan bagian dari penelitian Tesis dan penulis mengucapkan terima kasih kepada Ketua Prodi Manajemen Pesisir dan Teknologi Kelautan dan Direktur Pasca Sarjana yang telah memberi kesempatan untuk melanjutkan pendidikan di PPS UMI.

\section{DAFTAR PUSTAKA}

Badan Pusat Statistik Kabupaten Luwu Utara. 2018. Luwu Utara Dalam Angka. Masamba.

Candra A. 2003. Kajian Pemanfaatan Ruang Pesisir Pulau Natuna, Tesis Pascasarjana Institut Pertanian Bogor. Bogor

Gomez, E. D, dan H. T. Yap. 1988. Monitoring Reef Condition in Kenchington, R.A. and B. E. T. Hudson (ed.): Coral Reef Management Hand Book. UNESCO Regional Office for Science and Technology for South EastAsia. Jakarta.

Kementerian Kelautan dan Perikanan. 2013. Pedoman Teknis Penyusunan RZWP-3-K Provinsi. Direktoral Tata Ruang Laut Pesisir dan Pulau-Pulau Kecil. Jakarta.

Keputusan Menteri Negara Lingkungan Hidup Nomor 200 Tahun 2004 tentang Kriteria Baku Kerusakan dan Pedoman Penentuan Status Padang Lamun

Keputusan Menteri Negara Lingkungan Hidup Nomor 201 Tahun 2004 tentang Kriteria Baku dan Pedoman Penentuan Kerusakan Mangrove.

Peraturan Daerah No. 2 Tahun 2019 tentang Rencana Zonasi Wilayah Pesisir dan PulauPulau Kecil (RZWP-3-K) Provinsi Sulawesi Selatan 
Simamora, R. D. 2009. Studi

Keanekaragaman

Makrozoobentos di Aliran

Sungai Padang Kota Tebing

Tinggi. Skripsi. Departemen

Biologi. FMIPA. Universitas

Sumatra Utara. Medan.

Start dan Hovland. 2004. Tools for Policy Impact: A Handbook for Reasearchers. Research and Policy in Development

Programme. Overseas

Development Institute. London.

Undang-Undang Nomor 23 tahun 2007

tentang Pemerintah Daerah. 